\title{
Rewards Policy And Employee Motivation In The National Library Of Nigeria (NLN)
}

\begin{abstract}
By
Victoria Okojie

Abstract

This study focused on ranking twenty factors that influence employee motivation in the National Library of Nigeria as well as examining the reward policy of the organization. A descriptive survey method was used with the questionnaire as the main data collection instrument. The questionnaire used was adapted from Kovach's (1987) questionnaire on employee motivation and Kamdi's (2009) questionnaire on reward policies for employees. Out of the 100 questionnaires distributed, 81 were returned representing $81 \%$ return rate. Using simple statistical analysis, the study observed that employees of the National Library of Nigeria were most motivated by job security, salary and interesting work respectively. The study also observed that the reward programme in place at the National Library was not well communicated to staff and therefore there were a lot of contradicting views among staff on how the programme was implemented. Interestingly, staff were of the view that an efficient and effective reward programme will greatly enhance employee motivation and that a highly motivated workforce will lead to greater productivity and ultimately ensure that the National Library meets its stated goals. The study concludes by recommending that the management of the National Library of Nigeria should develop a well articulated, written reward policy which will be widely circulated among staff. It also suggests ways to address the security needs of staff and other key factors that influence employee motivation.
\end{abstract}

\section{Background and Purpose}

The twenty first century information age brings with it unique challenges in every facet of society. The workplace of today is beset with complex organizational factors that inter-relate and interact in ways that stimulate the dynamism of the workplace; thereby leading to the need for constant change and drive for excellence. For organizations to keep up with stiff competition and maintain a competitive edge, there is need to constantly evaluate the workplace environment - human, material and financial resources - to make it more efficient and effective. The methodologies of developing strong and durable relationships between organizations and employees to fulfill the changing needs of both parties and to meet the organizational goals are therefore imperative to the success of the organization. Traditionally, most reward and recognition systems within the organizational structure were vague and not usually understood by the employees because there were no set standards and even when there were standards, they were often set at the discretion of the management. In current organizational settings, this is no longer the case, as organizations understand the great gains derived by linking rewards and recognition to their business strategy (Flynn, 1998).

Public sector organizations usually expect employees to follow the rules and regulations, and perform the tasks assigned to them according to the standards set for them, while on the other hand, employees expect good working conditions, fair pay, fair treatment, secure career, power and involvement in decision making (Khan et. al. 2010). Since these expectations vary from organization to organization, Beer et. al. (1984) posit that it is important to understand what motivates an employee, what factors influence motivation, the various reward strategies that can be used and the extent to which rewards influence motivation in order to enhance productivity in an organization.

In his contribution, Carnegie (1975) emphasized the human aspects of management noting that it is 'people' who make an organization to succeed or fail. In the same vein, Ali and Ahmed (2009) stated that in the Information Age, people are now seen as the primary source of an organization's competitive advantage and that human capital is more essential than financial capital in determining an organizations' effectiveness. Since organizations are under constant pressure to enhance and improve their performance, management is looking more inwards at the interdependent relationships that exist between organizational performance and employee performance. Indeed, the importance of the human factor was put succinctly by Lawler (2003) when he stated that the way people are treated increasingly determines whether an organization will prosper or even survive. Flynn (1998) states that the primary focus of reward programmes is to examine how organizations classify their reward schemes, how they communicate with the employees and how clearly they understand the link between reward and performance. 


\section{Justification and Significance of Employee Motivation}

Smith (1994) notes that motivated employees are more productive in the workplace, therefore, the need to examine what motivates employees is critical to the survival of an organization. Motivating employees is one of the most complex and challenging functions of a manager and a manager who does not know what and how to motivate his employees plans to fail!. Bowen and Radhakrishna (1991) attribute this complexity to the fact that what motivates employees' changes constantly depending on a complex number of factors which could be intrinsic or extrinsic. For instance, Kovach (1987) observed in his research on factors that motivate employees, that as an employee's income increases, money becomes less of a motivator and that as an employee gets older, interesting work becomes more of a motivator. Research has shown that to motivate others is the most important task of management because it comprises the abilities to communicate, set an example, challenge, encourage, obtain feedback, involve, delegate, develop and train, inform, brief and provide a just reward.

Khan et. al. (2010) posit that organizational goals are directly proportional to the personal goals of an individual and that organizational productivity can be increased if employees are self-motivated towards their work rather than being directed. Therefore, managers play an important role in the motivation of employees. This is particularly true of service organizations such as libraries. According to Petcharak (2002), one of the main functions of the human resource manager is to keep the employees satisfied with their jobs and ensure continued motivation of employees. When the work environment is not satisfactory to the employee, his performance is poor and this ultimately leads to poor performance of the organization. Ballentine (2003) stated that the purpose of rewarding employees is to recognize excellent job performance, provide feedback, make it easier to get work done, encourage employees to be more productive and help management achieve their goal. Therefore, in order to ensure that the National Library of Nigeria attains its stated goals in an efficient and effective manner, it is pertinent that the employee reward policy is deployed in a way that engenders a motivated workforce. All things being equal, the motivated workforce will perform better on the job and deliver better quality service.

\section{Objectives}

The objectives of the study include:

1. To describe the ranked importance of the following twenty motivating factors on employees of the National Library of Nigeria: Job security, Sympathetic help with personal problems/welfare; Personal loyalty to employees; Interesting work; Good working conditions/environment; Tactful discipline; Salary/Good wages; Promotions and growth in the organization; Feeling of being in on things/being part of decision-making; Full appreciation of work done; Continuing Professional development/Training; Mentoring Scheme; Healthy competition among colleagues; Fair play/Equal opportunity; Interpersonal relationship with colleagues; Self-actualization; Self-esteem/Social; Meeting targets at the workplace; Power/Authority and Multi-tasking.

2. To find out how the results of this study compares with Maslow's motivation theory on Hierarchy of Needs.

3. To identify the types of reward programmes in the National Library of Nigeria.

4. To find out how reward programmes are administered in the National Library of Nigeria.

5. To suggest ways in which reward programmes in the National Library of Nigeria can be improved upon in order to increase employee motivation.

\section{Literature Review Reward Programmes in Organizations}

To understand the effect of reward systems on employee motivation, it is important to examine the concepts of reward and employee motivation. Reward has been defined in various ways by different scholars. According to Wilson (2010) reward can be defined as "an external agent administered when a desired act or task is performed, that has controlling and informational properties". He went further to explain that rewards are usually administered to increase the probability of a pre-determined response although rewards can increase or decrease the probability of an event occurring, depending on the saliency and direction of the controlling and informational aspects of the reward. Rewards can be verbal, physical or tangible. Organizations usually use pay, promotion, bonuses and other types of reward to engender staff to increase productivity. These are management tools which when used appropriately, contribute to an organization's effectiveness by influencing individual or group behavior (Cameron and Pierce, 1977; Gomez-Mejia and Balkin, 1992). 
The impact of rewards on both intrinsic and extrinsic motivation has been well documented in the literature. For instance, Deci (1971) stated that in intrinsically motivated behavior, there is no reward except with the task itself while reward and recognition programmes come within the discussion on extrinsically motivated behavior that occurs when an activity is rewarded by incentives that are not inherent in the task.

According to Page (2008), rewards can be defines as something that increases the frequency of an employee action which leads to improved performance. He noted that rewards can be very important to employees as it helps to build their confidence and satisfaction in the workplace and reminds them that the extra efforts they put into their work are noticed and rewarded.

A cursory look at the literature reveals two main categories of reward: monetary and non-monetary with many of the researchers acknowledging the increasing importance of non-monetary rewards.

The behaviourist perspective propounded by researchers like Cameron and Pierce (1994) and Eisenberger and Cameron (1996), take the view that tangible rewards like money tend to suppress intrinsic motivation in so far as it is evident in subsequent time spent on the task, but not when it is measured by verbal expressions of attitude. They found that the effect tended to occur when the reward was expected and independent of performance and concluded that tangible rewards had a small positive effect on attitude to the task if the reward was quality dependent. Verbal rewards, like praise, tended to have a positively reinforcing effect on both free time on the task and attitudes to the task.

Page (2008) listed the top three non-monetary rewards that employees want as: i. Opportunity to learn, develop and advance. ii. Flexible work hours. iii. Recognition. Rewards, especially non-monetary rewards in the workplace can be creative, powerful tools used by leaders to create a motivational environment, which employees may find to be meaningful and which will help them work at their optimal levels to accomplish organizational objectives.

\section{Employee Motivation}

The word "motivation" was originally derived from the Latin word "movre" which means "to move". However, over time various researchers have attempted to have a more comprehensive definition of the word and motivation has been defined in different ways, most of them agree that it is a goal- directed behaviour. Butkus and Green (1999) stated that the word motivation is derived from the word "motivate" which means to move, push or persuade to act to satisfy a need. However, Mol (1992) differentiated between the terms "movement" and 'motivation”. He described movement as carrying out a task in order to be compensated or remunerated while motivation was the voluntary involvement and decision of a person to carry out a task. In his contribution, Baron (1983) defined motivation as a set of processes concerned with a kind of force that energizes behavior and directs it towards achieving specific goals. He went on to state that not only motivation can influence performance, but that performance can also influence motivation, if followed by rewards. He concluded that organizations could benefit from implementing total reward programmes that focus on formal reward policies. In addition, he argued that there is a very close relationship between motivation and job performance, noting that performance and motivation are directly proportional to each other.

Page (2008) in his article on non-monetary incentives in the workplace, defined motivation as "the process that accounts for an individual's intensity, direction and persistence of effort toward attaining a goal. Thus, from the various definitions, it can be seen that primary concerns while discussing motivation are what energizes, channelizes, and sustains human behavior". Motivation has also been defined as the psychological process that gives behavior purpose and direction (Kreitner, 1995); a predisposition to behave in a purposive manner to achieve specific, unmet needs (Buford et. al., 1995); an internal drive to satisfy an unsatisfied need (Higgins, 1994) and as the inner force that drives individuals to accomplish personal and organizational goals (Lindner, 1998).

In their contribution, Shah and Shah (2010) defined motivation as inspiring people to work, individually or in groups in such a way as to produce best results; it is the will to act. They further stated that motivation is a general term applied to the entire class of drives, desires, needs, wishes and similar forces. They noted that to say that managers motivate their subordinates is to say that they do those things which they hope will satisfy these drives and desires and induce the subordinates to act in a desired manner. Shah and Shah (2010) listed the requisites to motivation as:

- We have to be motivated to motivate

- Motivation requires a goal

- Motivation once established, does not last if not repeated

- Motivation requires recognition 
- Participation has motivating effect

- Seeing ourselves progressing motivates us

- Challenge only motivates if you can win

- Everybody has a motivational fuse i.e. everybody can be motivated

- Group belonging motivates.

McCullagh (2005) classified motivation into two: intrinsic (self-motivated) and extrinsic motivation. He defined intrinsic motivation as an individuals' need to feel competency and pride in something while extrinsic motivation is the performance of an activity in order to attain some separate outcome and noted that people can be both intrinsically and extrinsically motivated. Deci (1975) in a report of an experiment concluded that if people are paid to do something they would otherwise have done out of interest, they will be less likely to do it in future without being paid. For this paper, the operational definition of motivation is a stimulus or force that drives an employee to do what he set out to do in order to achieve his personal and organizational goals.

\section{Motivation theories}

In the early $20^{\text {th }}$ century, money was regarded as the most important input into the production of goods and services. However, after a series of researches, known as the "Hawthorne Studies", conducted by Elton Mayo from 1924-1932 at the Hawthorne Works of the American Western Electricity Company in Chicago, it was observed that employees were not motivated solely by money but that employee behavior was linked to their attitudes (Dickson, 1973). The Hawthorne studies began the human relations approach to management, whereby the needs and motivation of employees become the primary focus of managers (Bedeian, 1993). Many theories have been propounded to examine the factors that contribute to employee motivation in an organization. These theories are important because they provide explanations to the reasons why employees are motivated, therefore, if properly applied; they could lead to having better motivated employees which ultimately may lead to increased productivity in organizations. The earliest motivation theories (pre-1960s) include, among others, Abraham Maslow's need hierarchy theory (1943); Fredrick Herzberg's dual factor theory (1959), and B.F. Skinner's reinforcement theory (1953).

i. Abraham Maslow's Need Hierarchy Theory (1943): Maslow's theory on the hierarchy of needs is one of the most popular theories of motivation. Maslow (1943) stated that employees had five levels of needs and that human needs were in the form of a hierarchy ascending from the lowest to the highest. He posited that no need can be fully gratified and that when a need that is substantially satisfied, it ceases to be a motivator. Maslow theorized that the lower level needs have to be satisfied before the next higher level need would motivate an employee. He concluded that to meet the needs of an employee, the employer had to understand the hierarchy of the need to which the employee belongs. Maslow categorized human needs as:

a. Physiological needs - these are needs that focus on sustaining human life such as food, water, warmth, shelter, sleep, medicine and education. Maslow stated that until these basic needs are satisfied to a large extent, no other motivating factor can operate.

b. Security or Safety needs - these are the next in hierarchy and focus on being free of physical danger and the fear of losing a job, property, food or shelter as well as protection against emotional disappointment.

c. Social needs - these are the needs that deal with the social aspect of man such as the need to belong and be accepted by others. It is the need for affection, acceptance and friendship.

d. Esteem needs - Maslow posited that as soon as people satisfy the need to belong, the next higher level of need is the need to be held in high esteem by themselves and others. He stated that these kinds of need produce satisfaction through power, prestige, status and self-confidence. It includes internal esteem factors such as selfrespect, autonomy, and achievements and external factors such as status, recognition and attention.

e. Need for self-actualization - this is the highest need in the hierarchy. It is the drive to become what one is capable of becoming, to maximize your full potential and to accomplish something. It includes needs such as growth, achieving one's potential and self-fulfillment.

Frederick Herzberg's Dual Factor or Hygiene Theory (Herzberg et. al., 1959): Herzberg's theory is a modification of Maslow's theory. He based his theory on two types of motivators - factors that result in satisfaction with one's job and those that result in dissatisfaction for employees at work. He stated that intrinsic factors are related to job satisfaction while extrinsic factors relate to dissatisfaction. His theory was based on the question "What do people want from their jobs?”. From the responses he received, he concluded that removing dissatisfying characteristics from a job does not necessarily make the job satisfying. He identified two major factors (motivators and hygiene factors) that could lead to job satisfaction. He noted that the motivators are 
intrinsic factors that permit psychological growth and development on the job such as achievement, recognition, responsibility, advancement, challenges and the work itself. On the other hand, hygiene factors are extrinsic and describe the conditions of work rather than the work itself. These include job security, salary, work conditions, company policy, administration, supervision, interpersonal relations with subordinates and supervisors, status and so on. Herzberg concluded that employers should be concerned with the job itself and not only with the work conditions.

iii. B. F. Skinner's Reinforcement Theory (Skinner, 1953): Skinner believes that the best way to motivate an employee is to continuously make positive changes in the external work environment. He noted that in as much as internal factors such as impressions, feelings, attitudes and other cognitive behavior affect employees; individuals are directed by what happens in the external environment of the organization. He concluded that managers should positively reinforce employee behaviours that lead to positive outcomes while behaviours that lead to negative outcomes should not be reinforced.

\section{Factors That Influence Employee Motivation}

Research has shown that a number of factors affect employee motivation. Lindner (1998) in his paper on understanding employee motivation, examined the ranked importance of ten motivating factors of employees at the Ohio State University's Piketon Research and Extension Centre and Enterprise Centre. He observed that the ranked order of motivating factors was: i. Interesting work. ii. Good wages. iii. Full appreciation of work done. iv. Job security v. Good working conditions. vi. Promotions and growth in the organization. vii. Feeling of being in on things. viii. Personal loyalty to employees. ix. Tactful discipline. x. Sympathetic help with personal problems. Kovach (1987) also conducted a similar study to find out the ranked order of motivational factors of industrial employees. He found that the ranked order was: i. Interesting work. ii. Full appreciation of work done. iii. Feeling of being in on things. Similarly, Harpaz (1990) listed the three most motivating factors as: i. interesting work. ii. good wages and iii. job security.

Furthermore, Mosley et. al. (2001) noted that there were three levels of employee motivation, namely: the direction of an employee's behavior, the level of effort and the level of persistence. In 1989, Daschler and Ninemeier investigated what employees may seek from the work environment and concluded that:

- Employees are individuals that come from different backgrounds, have different education with different experiences and their different family classes are all the factors in which their needs should be located

- The primary interest of employees is to satisfy their personal needs, ambitions, desires and goals

- An employee wants to satisfy his basic needs, linked to survival and security concerns and a desire to belong, to generate positive feelings from within and from others, and to be self-fulfilled.

- Most employees want fair and consistent company policies in matters affecting them; management that they can respect and trust; adequate working relationships with managers and co-workers; acceptable salaries and working environment; appropriate job security assurance; favourable job status; challenging work; work that yields a sense of personal achievement; expression of appreciation for good performance; increased responsibility; a chance to grow on the job; the feeling of importance and making a contribution to the organization; and participation in job-related matters that affect the employees.

The discrepancies in these research findings supports the idea that what motivates an employee differs from one employee to the other, from one organization to the other and at different time periods.

\section{National Library of Nigeria}

The National Library of Nigeria was established by the National Library Act of 1964 which was later repealed and substituted by the National Library Act No. 29 of 1970. It is a federal government parastatal under the Federal Ministry of Education which is responsible for ensuring access to the recorded knowledge for the progress and development of Nigeria. It is the "giant memory of the nation, its intellectual store-house and the data bank for its learning and remembering processes" (National Library of Nigeria, 2010). The main objectives of the National Library of Nigeria are:

a. To provide necessary support for intellectual efforts in all activities directed at progress and development

b. To ensure the availability of comprehensive and as near complete a collection of resources as possible, materials in existing knowledge in the world, and to ensure full access to such 
resources both within and outside the nation's boundaries.

c. To ensure a free flow of knowledge between Nigeria and other nations, thereby securing a place for the nation in the community of nations that depend on recorded knowledge and information for survival in a world of rapid advancement and competition of ideas.

The National Library of Nigeria is a public sector organization with about 1000 staff. The headquarters is in Abuja while it has twenty-three branches nationwide. It has seven departments: Administration, Finance \& Accounts, Collection Development and Processing, National Bibliographic Control, Research \& Development, Public Services and Virtual Library Services. The staff are guided by the public service rules and their work conditions are similar to those of other government agencies. Over time, staff of these organizations have been characterized by low morale, low productivity and low motivation. Since its services are important to national development, it is essential to examine the reward programmes in place, the factors that motivate staff and make suggestions on how staff motivation could be improved in order to increase productivity.

The questionnaire was distributed to 100 staff and 81 staff responded. An analysis of the demographic characteristics of the respondents shows that there were 33 females (41\%) and 48 males (59\%); 65 (80\%) Christians and 16 (20\%) Muslims as well as 23 (28\%) singles and 58 (72\%) married. The age range varied from 12 (15\%), 28 (35\%), 31 (38\%) and 10 (12\%) for respondents between 21yrs-30yrs; 31yrs-40yrs; 41yrs-50yrs and 51yrs-60yrs respectively. There were no respondents below 20yrs. As regards work experience, 24 (29.5\%) had less than 10yrs experience; 12 (15\%) had 11yrs-15yrs; 13 (16\%) had 16yrs-20yrs; 11 (13.5\%) had 21yrs-25yrs; 17 (21\%) had 26yrs-30yrs and 4 (5\%) had 31yrs35yrs experience. Respondents were drawn from all departments in the National Library of Nigeria as follows: 3 (4\%); 4 (5\%); 11 (14\%); 5 (6\%); 18 (22\%); 1 (1\%); 19 (24\%); 6 (7\%); and 14 (17\%) from Virtual Library, Chief Executive Officer, Finance \& Accounts, Research \& Development, Administration, Audit, National Bibliographic Control; Public Services and Collection Development and Processing departments respectively. As regards the status of the respondents, 27 (33\%) were junior staff while 54 $(67 \%)$ were senior staff. Out of the senior staff 23 (43\%) were professional librarians.

\section{Methodology}

The descriptive survey method was used in the study. The main instrument used was the questionnaire which was adapted from Kovach's (1987) questionnaire on employee motivation and Kamdi's (2009) questionnaire on reward systems which had $80 \%$ reliability level.

The target population was staff of the National Library of Nigeria headquarters with a total population of about 211. 100 staff were randomly selected to participate in the survey and 81 staff returned the filled questionnaire. The questionnaire was hand-delivered to respondents and collected on the same day. Three research assistants were used to administer and collect the filled questionnaire back. The questionnaire was sub-divided into three main sections. Section A sought information about the biographical data of respondents such as age, sex, marital status, religion, qualification, years of working experience and the department in which they work. In Section B, respondents were requested to rank the importance of twenty factors that motivated them in doing their work on a scale of 1-20, with 1 being the most important factor and twenty being the least important factor.

Face and content validity for the questionnaire were established using five professional staff. The questionnaire was pilot tested with ten randomly selected staff who were eventually excluded from participating in the main survey. Comments from these staff led to slight changes in the language of the questionnaire to make it more explicit and appropriate to the Nigerian environment. While Kovach's (2009) questionnaire listed ten factors, the number of factors examined in this study was increased to twenty. Section $C$ focused on the reward programme of the National Library of Nigeria. The questionnaire sought information on methods of rewarding staff, staff awareness of reward programmes, staff perception of the importance of reward systems and suggestions to improve the system. Data collected was analyzed using simple statistical tables with percentages. 


\section{Results and Discussions}

Out of a total of 100 respondents, 81 filled and returned the questionnaire. This represents a response rate of $81 \%$ which is statistically significant.

Ranked Order of Motivating Factors: The results show that the ranked order of motivating factors is shown in table 1.

Type of Reward Programmes: When asked what kind of reward policy was in place at the National Library of Nigeria, 58 (72\%) of the respondents said it was formal, 16 (20\%) said it was informal while 7 (8\%) said there was no reward policy in place. Respondents were further asked if the reward programme was monetary, non monetary or both. 12 (15\%) said it was monetary, $50(62 \%)$ said it was non-monetary, $13(16 \%)$ said it was both monetary and non-monetary while 6 (7\%) people did not respond to the question as shown in table 2 .

Non-Monetary Rewards Available: Respondents listed the following (table 3) as non-monetary rewards in the NLN: Awards: 15 (19\%); Letter of commendation: 30 (38\%); Verbal appreciation: 27 (33\%); Others: 2 (2\%) while 7 (8\%) did not respond to this question.

Table1: Ranked Order of Motivating Factors

\begin{tabular}{|l|l|l|}
\hline \multicolumn{1}{|c|}{ S/N } & \multicolumn{1}{|c|}{ FACTOR } & $\begin{array}{c}\text { PERCEN } \\
\text { TAGE }\end{array}$ \\
\hline 1. & Job security & $16 \%$ \\
\hline 2. & Good wages/salary & $10 \%$ \\
\hline 3. & Interesting work & $9 \%$ \\
\hline 4. & Good working conditions/environment & $8 \%$ \\
\hline 5. & Promotion and growth in organization & $6 \%$ \\
\hline 6. & Continuing Professional Development/Training & $6 \%$ \\
\hline 7. & Full appreciation of work done & $5 \%$ \\
\hline 8. & Fair play/Equity & $5 \%$ \\
\hline 9. & Power/Authority & $5 \%$ \\
\hline 10. & Interpersonal relationship with colleagues & $5 \%$ \\
\hline 11. & Sympathetic help with personal problems/welfare & $4 \%$ \\
\hline 12. & Feeling of being in on things/part of decision-making & $4 \%$ \\
\hline 13. & Healthy competition among colleagues & $4 \%$ \\
\hline 14. & Self-actualization & $2.5 \%$ \\
\hline 15. & Self esteem/social status & $2.5 \%$ \\
\hline 16. & Personal loyalty to employees & $2.5 \%$ \\
\hline 17. & Tactful discipline & $2.5 \%$ \\
\hline 18. & Meeting targets at the workplace & $1 \%$ \\
\hline 19. & Mentoring scheme & $1 \%$ \\
\hline 20. & Multi-tasking & $1 \%$ \\
\hline
\end{tabular}

Table 2: Types of Reward Programmes

\begin{tabular}{|l|l|l|}
\hline $\begin{array}{l}\text { Type of Reward } \\
\text { Programmes }\end{array}$ & No. of Respondents & Percentage \\
\hline Formal & 58 & $72 \%$ \\
\hline Informal & 16 & $20 \%$ \\
\hline None & 7 & $8 \%$ \\
\hline
\end{tabular}

Table 3: Types of Non-Monetary Rewards

\begin{tabular}{|l|l|l|}
\hline $\begin{array}{l}\text { Non-Monetary Rewards } \\
\text { Available }\end{array}$ & No. of Respondents & Percentage \\
\hline Awards & 15 & $19 \%$ \\
\hline Letter of Commendation & 30 & $38 \%$ \\
\hline Verbal Appreciation & 27 & $33 \%$ \\
\hline Others & 2 & $2 \%$ \\
\hline No response & 7 & $8 \%$ \\
\hline
\end{tabular}


Expectation from Employees: Respondents were given a free hand to state their expectations for reward from their employer. Their expectations include letter of commendation: 30 (37\%); money/end of year bonus: 15 (19\%); 13 (16\%) wanted the policy to be better communicated while $10(12 \%)$ said they expected their employer to be fair and treat all staff equally. 7 (9\%) said they expected to be sent on training programmes and 6 (7\%) expect to be given some form of award such as a plaque or medal.

Administration of Reward Programme: When asked if the reward system practiced in the NLN was properly communicated to all employees (table 5), 22 (27\%) said yes while 59 (73\%) said no. The 22 respondents who answered in the affirmative were requested to state how it was communicated. 6 of them said the reward system was communicated through memos and circulars and another 6 said it was through the official bulletin.

Frequency of Rewards: Respondents were requested to state how frequently employees were rewarded (table 6), 11 (14\%) each said monthly, quarterly and yearly, 42 or $51 \%$ said occasionally while $6(7 \%)$ people did not respond.

When asked how frequently the reward system was reviewed, the respondents said occasionally34(42\%); don't know- 32 (39\%), every 2yrs-3yrs- 8 (10\%) and every six months- 7 (9\%). Respondents were also asked if employee suggestions were considered when reviewing the reward system, 23 (28\%) said yes while 46 (57\%) said no and 12 (15\%) did not respond.

Eligibility of Employees for Rewards: Table 7 shows the response from the respondents when asked if all employees were eligible for rewards, 46 (57\%) said yes while 26 or $32 \%$ said no and 9 or $11 \%$ did not respond. The 26 respondents who said no, were further asked which levels of employees were eligible. 14 (54\%) said management staff only, 5 (19\%) said senior staff members and 7 (27\%) said permanent staff were eligible.

Table 4: Employee expectation of reward from employers

\begin{tabular}{|l|l|l|}
\hline Employee Expectation & No. of Respondents & Percentage \\
\hline Letter of commendation & 30 & $37 \%$ \\
\hline Money/End of year bonus & 15 & $19 \%$ \\
\hline Better communication on policy & 13 & $16 \%$ \\
\hline Equity/Fair treatment & 10 & $12 \%$ \\
\hline Training programmes & 7 & $9 \%$ \\
\hline Plaque/medal, etc & 6 & $7 \%$ \\
\hline
\end{tabular}

Table 5: Awareness of Reward Programme

\begin{tabular}{|l|l|l|}
\hline $\begin{array}{l}\text { Awareness of Reward } \\
\text { Programme }\end{array}$ & No. of Respondents & Percentage \\
\hline Yes & 22 & $27 \%$ \\
\hline No & 59 & $73 \%$ \\
\hline
\end{tabular}

Table 6: Frequency of Rewards

\begin{tabular}{|l|l|l|}
\hline Frequency of Rewards & No. of Respondents & Percentage \\
\hline Monthly & 11 & $14 \%$ \\
\hline Quarterly & 11 & $14 \%$ \\
\hline Yearly & 11 & $14 \%$ \\
\hline Occasionally & 42 & $51 \%$ \\
\hline No response & 6 & $7 \%$ \\
\hline
\end{tabular}

Table 7: Eligibility for rewards

\begin{tabular}{|l|l|l|}
\hline $\begin{array}{l}\text { Eligibility of all employees for } \\
\text { rewards }\end{array}$ & No. of Respondents & Percentage \\
\hline Yes & 46 & $57 \%$ \\
\hline No & 26 & $32 \%$ \\
\hline No response & 9 & $11 \%$ \\
\hline
\end{tabular}


Table 8: Categories of staff eligible for rewards

\begin{tabular}{|l|l|l|}
\hline $\begin{array}{l}\text { Categories of staff eligible for } \\
\text { rewards }\end{array}$ & No. of Respondents & Percentage \\
\hline Management staff only & 14 & $54 \%$ \\
\hline Senior staff & 5 & $19 \%$ \\
\hline Permanent staff & 7 & $27 \%$ \\
\hline
\end{tabular}

Criteria for Reward: Respondents were requested to state the criteria used for rewarding employees, their responses are shown in table 9, which includes: exceptional performance/hard work: 20 (25\%); long service: 14 (17.5\%); punctuality, neatness, etc: 22 (27.5\%); loyalty to the organization: $8(10 \%)$; good conduct: 7 (8\%) while 2 (2\%) said honesty. 8 (10\%) did not respond to this question. Asked in another way, respondents were requested to state which criteria were used for rewards and given certain options to pick from. 19 or $24 \%$ said increased productivity/results/outcome; $15 \quad(19 \%)$ said innovative and creative ideas; 13 (16\%) said long service while 28 (34\%) said staff were rewarded for all the reasons above. 6 (7\%) did not respond to the question. This indicates that staff believe that exceptional performance and long service were rewarded, which is a positive feedback to management's desire to get staff to work hard and be innovative. The fact that staff thought long service was rewarded could also discourage staff high turnover rates.

Selection Method: Respondents were asked how employees were selected for reward as shown in table 10. From the options listed, no respondent stated that it is through group vote or decision from a single manager. However, 49 (60\%) said it was through the decision of top officials of the organization and 29 (36\%) said they did not know and 3 (4\%) did not respond to the question.

How NLN Benefits: When asked how the organization benefits from the rewards and recognition programme, 53 or $65 \%$ said there was improved performance of staff while $12(15 \%)$ said there was reduced absenteeism and 16 (20\%) did not respond as shown in table 11.

Table 9: Criteria for reward

\begin{tabular}{|l|l|l|}
\hline Criteria for reward & No. of Respondents & Percentage \\
\hline $\begin{array}{l}\text { Exceptional performance/hard } \\
\text { work }\end{array}$ & 20 & $25 \%$ \\
\hline Long service & 14 & $17.5 \%$ \\
\hline Punctuality/Neatness, etc & 22 & $27 \%$ \\
\hline Loyalty to organization & 8 & $10 \%$ \\
\hline Good conduct & 7 & $8 \%$ \\
\hline Honesty & 2 & $2 \%$ \\
\hline
\end{tabular}

Table 10: Method for selection

\begin{tabular}{|l|l|l|}
\hline Selection Method & No. of Respondents & Percentage \\
\hline Decision of top management & 49 & $60 \%$ \\
\hline Do not know & 29 & $36 \%$ \\
\hline Group vote & 0 & $0 \%$ \\
\hline Decision from a single manager & 0 & $0 \%$ \\
\hline No response & 3 & $4 \%$ \\
\hline
\end{tabular}

Table 11: Staff perception on how NLN benefits from reward programme

\begin{tabular}{|l|l|l|}
\hline How NLN Benefits & No. of Respondents & Percentage \\
\hline Improved Performance & 53 & $65 \%$ \\
\hline Reduced absenteeism & 12 & $15 \%$ \\
\hline No response & 16 & $20 \%$ \\
\hline
\end{tabular}


Table12: Support to Non-Performers

\begin{tabular}{|l|l|l|}
\hline Support to Non-performers & No. of Respondents & Percentage \\
\hline Training & 36 & $44 \%$ \\
\hline Counseling & 16 & $20 \%$ \\
\hline Nothing is done & 23 & $29 \%$ \\
\hline No response & 6 & $7 \%$ \\
\hline
\end{tabular}

When asked if the reward system was well communicated, $73 \%$ said no! This implies that most of the employees were confused about how the reward system in place was managed. This view is supported by the fact that $51 \%$ of respondents said, in response to the question on frequency, that the rewards were administered occasionally. The fact that most of the respondents (37\%) said that they expected letter of commendation as a form of reward means that employees were not necessarily expecting money and that the management of the NLN could very easily meet the expectations of the employees. When asked how the employees to be rewarded were selected, 36\% said they did not know. 32\% also said that not all categories of staff are eligible for reward. This again suggests that there is a communication gap between the management and the employees in terms of the reward programme in place. On the other hand, when asked how the organization could benefit from an appropriate reward programme, 65\% said through improved performance. This is a strong indication that if the reward system is well managed and staff are aware of and understand the programme in place, they are likely to take better advantage of it, thereby become better motivated which will in turn will lead to improved performance and ultimately the NLN will be better able to fulfil its organizational objectives and goals.

How Non-Performers are Treated: When asked to state how non-performers were supported, respondents listed training - 36 (44\%); counseling $16(20 \%)$ and others (nothing is done) - 23 (29\%) respectively. 6 (7\%) did not respond to this question. Finally, respondents were asked if there is a review in the job of the employee, transfer of department, demotion, pay cut, or termination of appointment if there is no improvement in an employee's performance. Their responses were 19 (24\%); 18 (22\%); 3 (4\%); 0 (0\%) and 2 (2\%) respectively. Other answers given by 26 or $32 \%$ of the respondents included training, counseling and that nothing was done. 13 or $16 \%$ of respondents did not respond to this question.

\section{Comparison of Findings to Maslow's Hierarchy of Needs Theory}

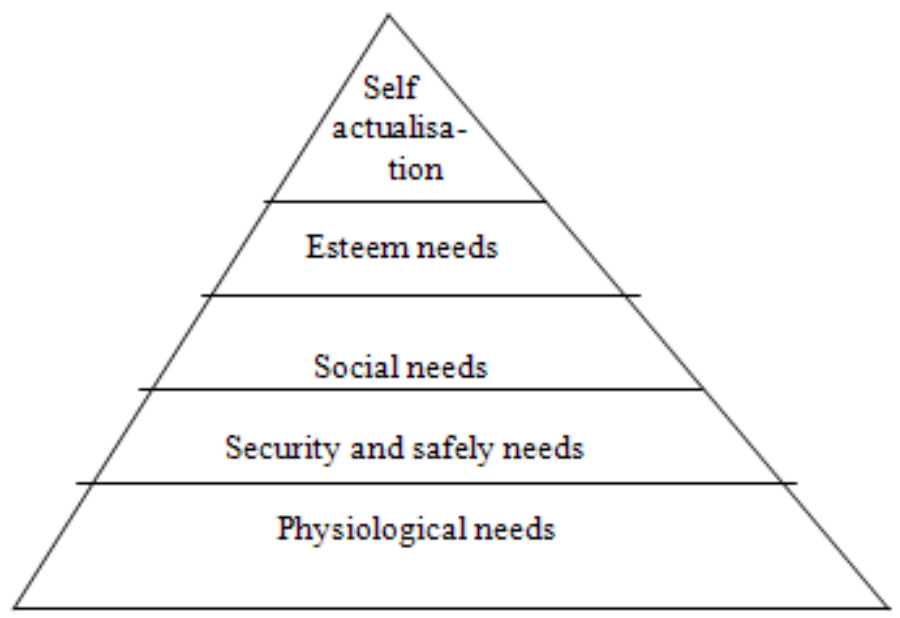

Fig. 1: Maslow’s Needs Hierarchy Theory 
A comparison of these findings gives some interesting insight into employee motivation. Job security which was ranked number one is a safety need. In a developing country such as Nigeria where unemployment levels are very high and at a time when there is global economic recession, governments are being forced to cut spending and cut jobs, thereby creating fear among employees. It is, therefore, not surprising that employees of the National Library of Nigeria ranked security as the most important motivating factor. Good salary which was ranked number two is a physiological need. Again, this is a pointer to the fact that Nigeria is a developing country and therefore people are still concerned with basic needs such as physiological needs. The number three ranked factor, interesting work is a self-actualization factor which is the last factor that is addressed in Maslow's theory. The fourth ranked factor, good working conditions, is a social need. The fifth ranking factors are both physiological (promotion) and self-actualization (training) factors. The seventh ranked factors, full appreciation of work done, fair play, power and interpersonal relationship with colleagues and the eleventh ranked factors (welfare, feeling of being in on things and competition) are also a mixture of esteem and social needs in Maslow's hierarchy theory. The fourteenth set of ranked factors, selfactualization, personal loyalty to employees, selfesteem and tactful discipline are self-actualization, esteem and social needs respectively. The eighteenth and last set of ranked factors are meeting target, mentoring and multi-tasking which are selfactualization needs.

The results of this study is different from some of the studies carried out in more developed countries which tend to rank interesting work as the highest motivating factor (Lindner, 1998; Kovach, 1987; Harpaz, 1990). Maslow's theory which lists physiological and safety needs as the basic needs to be met before others is to some extent upheld by this study. However, contrary to Maslow's theory, the range of other motivational factors in the National Library of Nigeria is mixed. Therefore, Maslow's conclusions that lower level motivational factors must be met before ascending to the next level were not confirmed by this study.

The implications of this study for the management of the National Library of Nigeria are numerous. If the management wants to address the issue of employee motivation, the main focus should be on addressing the security and safety issues. Staff must be reassured that their jobs are secure if they perform well and the fear of losing one's job must be addressed.
This is likely to boost the morale of staff and motivate them to better performance. Although the management of the National Library of Nigeria may not be able to directly address the second factor salary - by unilaterally increasing pay outside the public service prescription, it is important that management is aware of the issue and find others ways of compensating staff, where possible. The third, fourth and fifth factors which are selfactualization (interesting work, promotion) and social (good working conditions) factors implies that management needs to find ways of improving the work conditions, increasing training programmes and running programmes that help staff pass their promotion examinations. These can be addressed by providing a cleaner office, doing maintenance work at the appropriate time, providing the necessary work tools, running in-house training programmes and so on. Other ways of addressing self-actualization needs may include job enrichment, job enlargement and using non-monetary rewards.

The results of this study were also compared with Herzberg's theory (1959). Herzberg's conclusion that employees should be more concerned with intrinsic factors such as achievement, recognition, responsibility, advancement and challenges do not hold in the National Library of Nigeria. Rather, the study shows that staff are more concerned about extrinsic factors such as job security, salary and work conditions. Therefore, more efforts should be focused on improving extrinsic factors in order to get staff better motivated.

Regardless of which theory is applied, the policy that should be put in place should take cognizance of the fact that employee salary, job security and interesting work appear to be important links to higher motivation. Therefore, as observed by Lindner (1998), options such as job enlargement (number of tasks), job enrichment (variety of work), promotions, internal and external stipends, monetary and nonmonetary rewards should be considered in developing a policy on employee motivation.

\section{Suggestions and Recommendations}

From the findings of this study, the following suggestions are recommended to the management of the National Library of Nigeria (NLN):

i. The management of the NLN should, as a matter of urgency, develop a clearly stated, well articulated reward policy for the organization.

ii. A cross-section of employees should be part of the process of drawing up, reviewing and administering the policy. 
iii. The reward policy should be circulated to all staff.

iv. The safety needs of staff should be addressed as well as other factors identified as contributing to the motivation of staff. Skinner's (1953) reinforcement theory states that the best way to motivate an employee is to make positive changes to the external work environment continuously and that employee behaviours that yield positive outcomes should be reinforced. There is every probability that if this theory is applied to the staff of the National Library of Nigeria, staff motivation and productivity will increase.

\section{Conclusion}

This study gives an insight into which factors motivate staff of the National Library of Nigeria in their workplace and their perception of the reward programme in place. The study reveals that many staff are not aware of the reward programme in place and may not understand clearly how the programme operates hence, there is need for the Management of the National Library of Nigeria to put a formal policy in place. The management of the National Library of Nigeria therefore, needs to address the issue of having a well articulated reward policy which will motivate staff to work harder. This will ultimately result in higher productivity, thereby ensuring that the National Library achieves its stated goals and objectives. The implication of the study is that most of the employee motivation theories are not fully operational in the National Library of Nigeria. Also, the factors that influence motivation do not necessarily come in stringent steps and they vary from one employee to another.

\section{Reference}

Ali, R. and Ahmed, M. S. (2009). The impact of reward and recognition programs on employee's motivation and satisfaction: an empirical study. International Review of Business Research papers, Vol. 5 No. 4, pp. 270-279 Available at http://www.bizresearchpapers.com/22.reenq.pdf

(accessed 8 Nov., 2010).

Ballentine, A. (2003) Non-monetary rewards in the workplace. Available at www.mightystudents.com/.../non.monetary.rewa rds.workplace.9716?..-united states. (accessed 8 Nov., 2010).

Baron, R. A. (1983). Behaviour in organizations. New York: Allyn \& Bacon, Inc.

Bedeian, A.G. (1993). Management, $3^{\text {rd }}$.ed. New York: Dryden Press.
Beer, M., Spector, B., Lawrence, P. R., Mills, D. Q., and Walton, R. E. (1984). Managing human assets. New York: The Free Press.

Bowen, B.E. and Radhakrishna, R.B. (1991). Job satisfaction of agricultural education faculty: a constant phenomena. Journal of Agricultural Education, Vol.32, No. 2, pp.16-22

Buford, J. A. Jr., Bedeian, A. G. and Lindner, J. R. (1995). Management in Extension, $3^{\text {rd }}$. ed. Columbus, Ohio: Ohio State University Extension.

Butkus, R. T. and Green, T. B. (1999). Motivation, beliefs and organizational transformation. Organizational Quorum Books.

Cameron, J. and Pierce, W. D. (1994). Reinforcement, reward and intrinsic motivation: a meta-analysis. Review of Educational Research, Vol. 64, pp. 363-423.

Carnegie, D. (1975). Managing through people. New York: Dale Carnegie \& Associates, Inc.

Daschler, P.J. and Ninemeier, J.D. (1989). Supervision in the Hospitality Industry. East Lansing, MI: Educational Institute American Hotel \& Motel Association.

Deci, E. L. (1971). Effects of externally mediated rewards on intrinsic motivation. Journal of Personality and Social Psychology, Vol. 18, pp. 105-115.

Deci, E.L. (1975). Intrinsic Motivation. New York: Plenum Publishing Co. Japanese Edition, Tokyo:Seishin Shobo, 1980.

Dickson, W. J. (1973). Hawthorne experiments. In C. Heyel (ed.). The encyclopedia of management, $2^{\text {nd }}$ ed. pp. 298-302. New York: Van Nostrand Reinhold.

Eisenberger, R. and Cameron, J. (1996). Detrimental effects of reward: reality of myth? American Psychologist, Vol.51, pp. 1153-1166.

Flynn, G. (1998). Is your recognition program understood? Workforce, Vol. 77, No. 7, pp. 3035.

Gomez-Mejia, L.R. and Balkin, D. B. (1992). Determinants of faculty pay I an agency theory perspective. The Academy of Management Journal, Vol. 35, No. 5, pp. 921-955. http://www.jstor.org/stable/256535.

Harpaz, I. (1990). The importance of work goals: an international perspective. Journal of International Business Studies, Vol.21. pp. 75-93.

Herzberg, F., Mausner, B. and Snyderman, B.B. (1959). The motivation to work. New York: John Wiley \& Sons.

Higgins, J. M. (1994). The management challenge. $2^{\text {nd }}$ ed. New York: Macmillan. 
Kamdi, A. (2009). Questionnaire on reward programs in manufacturing/service industry. Available at http://hrmba.blogspot.com/2010/01/questionnair e-on-reward-program-in.html.

Khan, K. U., Farooq, S. U. and Ullah, M. I. (2010). "The relationship between rewards and employee motivation in commercial banks of Pakistan" Research Journal of International Studies-Issue 14. Available at http://www. eurojournals.com/rjis_14_06.pdf. (accessed 25 Oct., 2010).

Kovach, K.A. (1987). What motivates employees? Workers and supervisors give different answers. Business Horizons, vol. 30. Pp. 58-65.

Kreitner, R. (1995). Management, $6^{\text {th }}$ ed. Boston: Houghton Mifflin Company.

Lawler, E. E. (2003). Treat people right. San Francisco: Jossey-Bass Inc.

Lindner, J. R. (1998). Understanding employee motivation. Journal of Extension, Vol. 36, No. 3, Research in Brief, 3RIB3. Available at http://www.joe.org/joe/1998june/rb3.php. (accessed 10 Nov., 2010).

Maslow, A. H. (1943). A theory of human motivation. Psychological Review. pp. 370-396

McCullagh, P. (2005). Sport and exercise psychology lecture. Cal State University East Bay.10/27.

Mol, A. (1992). Motivating subordinates. IPM Journal, Vol. 11, no. 2, pp.19-22.

Mosley, D.C., Megginson, L.C. and Pietri, P.H. (2001). Supervisory Management. Cincinnati, $\mathrm{OH}$ : South-Western College Publishing.

Nahid, S. and Rehman, K. (2009). Foreign banks are more efficient a myth or fact? International
Journal of Business and Management, Vol. 4, No. 11, Available at www.ccsenet.org/journal.html. (accessed on 8 Nov., 2010).

National Library of Nigeria (2010). National Library of Nigeria. Available at http://www.nlnig.org. (accessed on 27 Dec., 2010).

Page, L. (2008). Do not show me the money? The growing popularity of non-monetary incentives in the workplace. Available at http://www.oppapers.com/essays/Non-moneatryincentives-workplaces/155356. (accessed on 27 Dec., 2010).

Petcharak, P. (2002). The assessment of motivation in the Saint Paul Hotel employees. Ms. Thesis, UW-Stout. Available at http://minds.wisconsin.edu/handle/1793/40589?s how=full.

Shah, K. and Shah, P. J. (2010?). "Motivation” Available at http://scribd.com/doc/6564596/motivation. (accessed on 8 Nov., 2010).

Skinner, B.F. (1953). Science and Human Behavior. New York: Free Press.

Smith, G.P. (1994). Motivation. In W. Tracey (ed.), Human resources management and development handbook. $2^{\text {nd }}$ ed.

Wilson, G. (2010), The effects of external rewards on intrinsic motivation. Available at http:// www.abcbodybuilding.com/rewards.pdf. (accessed on 8 Nov., 2010). 